\title{
Changes in the fish community of the Kpong Headpond, lower Volta River, Ghana after 25 years of impoundment
}

\author{
Theodore Quarcoopome ${ }^{1}$, Francis Amevenku ${ }^{1} \&$ Patrick Ofori-Danson ${ }^{2}$ \\ 1. CSIR-Water Research Institute,P.O. Box AH 38,Achimota, Ghana; qpome@yahoo.com, fkyamevenku@yahoo.com \\ 2. Department of Oceanography \& Fisheries, University of Ghana, P.O. Box LG 99, Legon, Ghana; ofdan@ug.edu.gh
}

\author{
Received 08-X-2010. Corrected 08-IV-2011. Accepted 09-V-2011.
}

\begin{abstract}
The Kpong Headpond was the second created on the Volta River after Akosombo Dam, primarily as a source of hydroelectric power generation and potable water supply, and additionally, it has supported some fish production in Ghana since impoundment. The changes in fish community of the Kpong Headpond were studied to provide baseline information for strategies formulation to support the socio-economic development of the reservoir. The study identified changes in the fish community of the reservoir by comparing occurrence, composition, relative abundance and relative importance estimates of fish species, families and trophic groups, from available previous studies in the reservoir. From the collated information all fishes identified in the reservoir were categorised based on occurrence and importance as disappeared, appeared, permanent, declined or important, to show current status. The results indicated that the fish community has experienced a shift in the composition and relative abundance of important species, families and trophic groups in terms of number and weight, while remaining ecologically balanced. Representatives of the families Osteoglossidae, Centropomidae and Characidae have declined while representatives of the families Claroteidae, Cyprinidae and Cichlidae have increased. The aufwuch-detritus and herbivores declined while semi-pelagic omnivores increased resulting in a shift in dominance to benthic and semi pelagic omnivores. The appearance of five species and the disappearance of 25 others indicated a dynamic restructuring of the fish community in the reservoir, as expected. Enforcement of fishing regulations including the use of appropriate gear and fishing methods, fishery access control, promotion of culture-based fisheries and improvement in fisher education are recommended topics for sustainable fisheries in the reservoir. Rev. Biol. Trop. 59 (4): 1685-1696. Epub 2011 December 01.
\end{abstract}

Key words: fish community, Kpong Headpond, impoundment, reservoir.

The number of reservoirs is steadily growing in all parts of the world with many more rivers being dammed in view of the importance of reservoirs as vital aquatic ecosystems that provide important environmental and socioeconomic benefits (Miranda 1999). In 1999, there were about 60000 reservoirs worldwide with a volume larger than $10 \times 10^{6} \mathrm{~m}^{3}$ representing a total volume exceeding $6500 \mathrm{~km}^{3}$ and a surface of about $400000 \mathrm{~km}^{2}$ (Miranda 1999). In the last 4-5 decades in Ghana, many reservoirs such as the Weija, Barekese, Kpong, Vea and
Tono have been formed by damming Rivers Densu, Owabi, Volta, White Volta and Tono, respectively. Generally, the purpose of damming includes irrigation, hydroelectric power generation, flood control, public water supply, recreation, navigation and fisheries (Bhukaswan 1980). The Kpong reservoir was purposely created for hydro-electric power generation but has been put to several uses including potable water supply source, fisheries, transport and irrigation, thus contributing to fish production and socioeconomic development. 
Various aspects of the fish fauna of the Kpong Headpond have been studied both before and after impoundment. Vanderpuye (1982), in a pre-impoundment study, provided information on the baseline conditions against which future changes in the fish populations could be measured. During post-impoundment studies, Dankwa (1982) and Antwi \& Ofori-Danson (1993) reported changes in various aspects of the fish fauna. The information on changing characteristics of fish populations such as catch, effort, abundance, size composition, sex, size at first maturity, growth, mortality among others, are very important aspects to consider when planning management programmes to ensure the achievement of the objective of optimum production.

This study formed part of the work by Quarcoopome et al. (2007) on the Kpong Headpond which had the general objective of assessing the state of the fish fauna. The specific objective was to assess the fish community of this reservoir since impoundment in relation to species composition, relative abundance, trophic status and ecological balance with a view to providing information to support efforts towards effective planning, use, management and conservation of the reservoir for socioeconomic development.

\section{MATERIALS AND METHODS}

Study area: The Kpong Headpond (Fig. 1) was formed in 1981 in response to increased demand for electricity following rapid expansion in industrialisation especially in major cities such as Accra-Tema, Kumasi and Sekondi-Takoradi Municipalities, as well as Akosombo after the construction of the Akosombo Dam. The reservoir, spanning a shoreline of $50 \mathrm{~km}$, was built at Natriku $25 \mathrm{~km}$ downstream of the existing Akosombo Dam by damming River Volta. It covers a surface area of about $35 \mathrm{~km}^{2}$ with a maximum depth of approximately $15 \mathrm{~m}$ and a mean depth of $5 \mathrm{~m}$ (Anon 1977). The presence of many small islands, forming rapids namely Senchi and Kpong rapids in the Northern and Southern sections respectively,

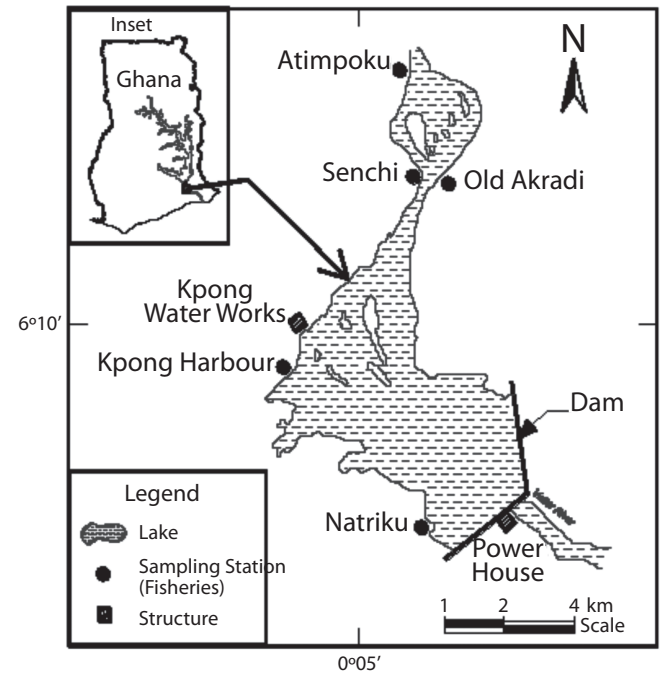

Fig. 1. Kpong Headpond, lower Volta River, Ghana showing sampling stations (adapted from Dankwa 1982).

characterize the reservoir. The mean annual flow rate of water through the reservoir was 1 $183 \mathrm{~m}^{3} / \mathrm{s}$ and water retention time was five days according to Vanderpuye (1982). The reservoir is a concrete dam which is flanked by rock and clay dykes with a total installed capacity of 160 megawatts in four units (Volta River Authority website; www.vra.com).

The reservoir supports agricultural activities such as fishing, crop farming and livestock rearing and serves as a source of water for generation of electricity, potable water production, irrigation and transportation. The rainfall pattern was bimodal with peaks in June and September while the dry season spanned November and March. The vegetation falls within the semi deciduous rain forest and coastal savanna transition zones. The area is generally low lying with topographic elevation of $15 \mathrm{~m}$ above mean sea level but rises steadily to the Northwest on to the Akwapim-Togo ranges (Benneh \& Dickson 1980).

Data collection and analysis: A list of fish species identified from previous studies were compiled from Vanderpuye (1982), Dankwa (1982), Antwi \& Ofori-Danson (1993) 
and Quarcoopome et al. (2007) all of whom used experimental fishing involving sets of $100 \mathrm{~m}^{2}$ gill nets for sampling. Vanderpuye (1982), however, used additional sampling methods namely hook and line, cast net, rotenone, beach seine and cane or basket traps for his pre-impoundment study. The key to fish identification was provided by Leveque et al. (1992), Leveque \& Paugy (1984) and LoweMcConnell (1972). The different types of fishing gear and important commercial fish species were obtained by inspection of commercial catches as well as from interviews and interactions with local fishermen at Kpong Harbour, Atimpoku, Senchi and Natriku.

Other information compiled from the afore-mentioned studies included estimates of relative abundance of fish species, families and trophic groups as well as ecological balance. Estimates of relative abundance in terms of number for each species and family was obtained by calculating its percentage composition of the sum total of the number of fish species and families respectively in each study. Similarly, estimates of relative abundance in terms of weight for each species and family was obtained by calculating its percentage composition of the sum total of the weight of all fish species and families respectively in each study. The relative importance of each species and family in terms of number and weight was determined as the one contributing at least $4 \%$ to the respective total number and weights of fish species and families sampled in a particular study.

There were four trophic (food habit) groups of fishes namely aufwuch-detritus and herbivores, semi pelagic omnivores and benthic omnivores (forage fishes) and piscivores adapted from Dankwa (1982) and based on Evans \& Vanderpuye (1973). Ecological balance of the fish community was represented by the ratio of forage fishes to piscivorous fishes $(\mathrm{F} / \mathrm{C}$ ratio) in terms of number and weight. The relative importance of each trophic group was determined by its percentage contribution to the respective pooled data of number and weight of all fish species sampled in a particular study.

From all the information obtained, comparisons were made and the changes determined and analysed. Fish species were categorised based on occurrence as either disappeared or appeared or permanent and based on relative abundance and importance as either declined or important according to the following legend.

Disappeared: Species not occurring in all subsequent studies after first occurrence either in Vanderpuye (1982) or Dankwa (1982) or Antwi \& Ofori-Danson (1993).

Appeared: Species occurring for the first time in Quarcoopome et al. (2007) and not occurring in the pre-impoundment and other post-impoundment studies.

Permanent: Species occurring in all preimpoundment and post-impoundment studies.

Declined: Species that occur in relatively lower numbers and weight in Antwi \& Ofori-Danson (1993) and Quarcoopome et al. (2007) compared to Vanderpuye (1982) and Dankwa (1982).

Important: Species occurring in Quarcoopome et al. (2007) and contributing at least $4 \%$ to total sampled weight and numbers.

\section{RESULTS}

Fish species composition and categorisation: The results took into account changes in nomenclature of 13 fish species. Table 1 presents the compilation of all fish species identified in both pre-impoundment and postimpoundment studies undertaken on the Kpong Headpond by Vanderpuye (1982), Dankwa (1982), Antwi \& Ofori-Danson (1993) and Quarcoopome et al. (2007).

Table 2 gives the categorisation by the authors of all fish species identified in the reservoir since impoundment. All estuarine species namely Caecula cephalopeltis, Doryichthys 
TABLE 1

List of fish species identified in Kpong Headpond, Ghana during 25 years of impoundment

\begin{tabular}{|c|c|c|c|c|}
\hline Species & Pre-impoundment ${ }^{1}$ & $\begin{array}{c}1 \text { year after } \\
\text { impoundment }{ }^{2}\end{array}$ & $\begin{array}{l}8 \text { years after } \\
\text { impoundment }\end{array}$ & $\begin{array}{l}25 \text { years after } \\
\text { impoundment }\end{array}$ \\
\hline Aplocheilichthys normani & $*$ & & & \\
\hline Auchenoglanis occidentalis & & $*$ & $*$ & $*$ \\
\hline Bagrus bajad & & $*$ & $*$ & $*$ \\
\hline Barbus leonensis & $*$ & & & \\
\hline Barbus macrops & $*$ & $*$ & $*$ & $*$ \\
\hline Barbus spp. & & $*$ & & \\
\hline Brienomyrus brachyistius & & & & $*$ \\
\hline Brycinus imberi & & $*$ & & \\
\hline Brycinus leuciscus & & $*$ & $*$ & $*$ \\
\hline Brycinus longipinnis & $*$ & & $*$ & $*$ \\
\hline Brycinus macrolepidotus & & * & $*$ & \\
\hline Brycinus nurse & $*$ & & & \\
\hline Caecula cephalopeltis & $*$ & & & \\
\hline Campylomormyrus tamandua & & & & $*$ \\
\hline Chromidotilapia guntheri & $*$ & * & $*$ & $*$ \\
\hline Chrysichthys auratus & $*$ & $*$ & $*$ & $*$ \\
\hline Chrysichthys furcatus & * & & & \\
\hline Chrysichthys maurus & $*$ & & & $*$ \\
\hline Chrysichthys nigrodigitatus & & * & $*$ & $*$ \\
\hline Chrysichthys walker & $*$ & * & $*$ & $*$ \\
\hline Clarias anguillaris & $*$ & * & $*$ & * \\
\hline Clarias senegalensis & & $*$ & & \\
\hline Ctenopoma petherici & $*$ & * & & * \\
\hline Odaxothrissa mento & $*$ & & & $*$ \\
\hline Distichodus spp. & & & & $*$ \\
\hline Distichodus rostratus & $*$ & & & \\
\hline Doryichthys aculeatus & $*$ & & & \\
\hline Eleotris senegalensis & $*$ & & & \\
\hline Epiplatys senegalensis & $*$ & & & \\
\hline Gerres melanopterus & $*$ & & & \\
\hline Gobius guineensis & * & & & \\
\hline Gymnarchus niloticus & & $*$ & $*$ & $*$ \\
\hline Hemichromis bimaculatus & $*$ & $*$ & $*$ & $*$ \\
\hline Hemichromis fasciatus & $*$ & $*$ & $*$ & $*$ \\
\hline Hepsetus odoe & $*$ & & & $*$ \\
\hline Heterobranchus longifilis & & & & $*$ \\
\hline Heterotis niloticus & & * & & \\
\hline Hippopotamyrus psittacus & $*$ & * & & \\
\hline Hippopotamyrus pictus & & $*$ & & \\
\hline Hydrocynus forskalii & & $*$ & $*$ & $*$ \\
\hline Hyperopisus bebe & * & * & & $*$ \\
\hline Labeo senegalensis & & * & & \\
\hline Lates niloticus & & $*$ & $*$ & \\
\hline
\end{tabular}


TABLE 1 (Continued)

List of fish species identified in Kpong Headpond, Ghana during 25 years of impoundment

\begin{tabular}{|c|c|c|c|c|}
\hline Species & Pre-impoundment ${ }^{1}$ & $\begin{array}{c}1 \text { year after } \\
\text { impoundment }{ }^{2}\end{array}$ & $\begin{array}{c}8 \text { years after } \\
\text { impoundment }{ }^{3}\end{array}$ & $\begin{array}{l}25 \text { years after } \\
\text { impoundment }\end{array}$ \\
\hline Malapterurus electricus & $*$ & $*$ & & \\
\hline Marcusenius furcidens & $*$ & & & \\
\hline Marcusenius senegalensis & $*$ & & $*$ & \\
\hline Mormyrops deliciosus & $*$ & $*$ & $*$ & $*$ \\
\hline Mormyrus hasselquisti & & $*$ & & \\
\hline Mormyrus rume & & * & $*$ & \\
\hline Mugil cephalus & & $*$ & & \\
\hline Oreochromis niloticus & $*$ & $*$ & $*$ & $*$ \\
\hline Parachanna obscura & $*$ & & $*$ & $*$ \\
\hline Paradistichodus dimidiatus & $*$ & & & \\
\hline Pellonula afzeluisi & $*$ & $*$ & $*$ & \\
\hline Petrocephalus bane & & $*$ & & $*$ \\
\hline Petrocephalus bovei & $*$ & $*$ & $*$ & $*$ \\
\hline Parailia pellucid & $*$ & & & \\
\hline Plectorhynchus macrolepis & & $*$ & & \\
\hline Pollimyrus isidori & $*$ & & $*$ & $*$ \\
\hline Polypterus endlicheri & & & & $*$ \\
\hline Polypterus senegalus & $*$ & $*$ & $*$ & $*$ \\
\hline Protopterus annectens & $*$ & $*$ & $*$ & \\
\hline Raiamas senegalensis & & & $*$ & \\
\hline Sarotherodon galileus & $*$ & $*$ & $*$ & $*$ \\
\hline Sarotherodon melanotheron & $*$ & $*$ & & \\
\hline Schilbe intermedius & & & & $*$ \\
\hline Schilbe mystus & & $*$ & $*$ & $*$ \\
\hline Sierrathrissa leonensis & $*$ & & $*$ & \\
\hline Steatocranus irvinei & $*$ & $*$ & $*$ & $*$ \\
\hline Synodontis courteti & $*$ & & & \\
\hline Synodontis eupterus & $*$ & $*$ & $*$ & $*$ \\
\hline Synodontis gambiensis & $*$ & $*$ & $*$ & $*$ \\
\hline Synodontis nigrita & $*$ & & & \\
\hline Synodontis ocellifer & & $*$ & $*$ & $*$ \\
\hline Synodontis schall & $*$ & $*$ & $*$ & $*$ \\
\hline Synodontis sorex & & $*$ & & \\
\hline Synodontis velifer & & & $*$ & $*$ \\
\hline Synodontis violaceus & * & & & \\
\hline Tetraodon lineatus & $*$ & $*$ & $*$ & $*$ \\
\hline Tilapia guineensis & & & & $*$ \\
\hline Tilapia zillii & $*$ & & $*$ & $*$ \\
\hline TOTAL & 50 & 46 & 39 & 43 \\
\hline
\end{tabular}

\footnotetext{
$*=$ present

1 = Vanderpuye $(1982)$

2 = Dankwa (1982)

$3=$ Antwi \& Ofori-Danson (1993)

4 = Quarcoopome et al. (2007)
} 
TABLE 2

Description of current status of fish species in Kpong_Headpond after 25 years of impoundment

\begin{tabular}{|c|c|c|c|c|}
\hline Disappeared & Declined & Appeared & Important & Permanent \\
\hline A. normani & B. bajad & B. brachyiustus & B. macrops & B. macrops \\
\hline B. leonensis & C. anguillaris & C. tamandua & B. leuciscus & C. guntheri \\
\hline B. imberi & C.pethereci & H. longifilis & C. nigrodigitatus & C. auratus \\
\hline B. nurse & D. rostratus & P. endlicheri & H. bimaculatus & C.walker \\
\hline C. senegalensis & Distichodus spp. & S. intermedius & H.fasciatus & C. anguillaris \\
\hline E. senegalensis & H. odoe & & H. bebe & H. bimaculatus \\
\hline H. niloticus & H.psittacus & & M. deliciousus & H. fasciatus \\
\hline H.pictus & Lates niloticus & & S. galileus & M. deliciosus \\
\hline L. senegalensis & M. electricus & & S. intermedius & O. niloticus \\
\hline M. furcidens & S. ocellifer & & T. guineensis & P. bovei \\
\hline \multirow[t]{2}{*}{ M. hasselquisti } & & & & S. galileus \\
\hline & & & & S. irvinei \\
\hline P. dimidiatus & & & & S. eupterus \\
\hline P. pellucida & & & & S. gambiensis \\
\hline R. senegalensis & & & & S. schall \\
\hline S. courteti & & & & T. lineatus \\
\hline \multicolumn{5}{|l|}{ S. nigrita } \\
\hline \multicolumn{5}{|l|}{ S. sorex } \\
\hline \multicolumn{5}{|l|}{ S. violaceus } \\
\hline \multicolumn{5}{|l|}{ C. cephalopeltis } \\
\hline \multicolumn{5}{|l|}{ D. culeatus } \\
\hline \multicolumn{5}{|l|}{ E. senegalensis } \\
\hline \multicolumn{5}{|l|}{ G. melanopterus } \\
\hline \multicolumn{5}{|l|}{ G. guineensis } \\
\hline \multicolumn{5}{|l|}{ M. cephalus } \\
\hline \multicolumn{5}{|l|}{ P. macrolepis } \\
\hline 25 & 10 & 5 & 10 & 16 \\
\hline
\end{tabular}

aculeatus, Eleotris senegalensis, Gerres melanopterus, Gobius guineensis, Mugil cephalus and Plectorhynchus macrolepis are categorised as 'disappeared'. Some freshwater species categorised as 'disappeared' include Barbus leonensis, Brycinus nurse, Clarias senegalensis, Heterotis niloticus, Hippopotamyrus pictus, Labeo senegalensis, Mormyrus hasselquisti, Raiamas senegalensis as well as three Synodontis species.

The species grouped as "appeared" in this study are those that were reported for the first time in the reservoir namely: Brienomormyrus brachyistius, Campylomormyrus tamandua,
Heterobranchus longifilis, Polypterus endlicheri and Schilbe intermedius.

Species grouped as "declined" include Bagrus bajad, Clarias anguillaris, Ctenopoma pethereci, Distichodus spp., Hepsetus odoe, Hippopotamyrus psittacus and Synodontis ocellifer. The other species in this group are: Lates niloticus and Malapterurus electricus.

The 10 fish species grouped as "important" are: Barbus macrops, Brycinus leuciscus, Chrysichthys nigrodigitatus, Hemichromis bimaculatus, Hemichromis fasciatus, Hyperopisus bebe, Mormyrops deliciosus, Sarotherodon galileus, Schilbe intermedius and Tilapia guineensis. 
A total of 16 fish species grouped as "permanent" include Barbus macrops, Chrysichthys auratus, Hemichromis bimaculatus, Hemichromis fasciatus, Oreochromis niloticus, Sarotherodon galileus, 3 Synodontis species, Tetraodon lineatus among others.

Changes in relative abundance of the fish community: Chrysichthys auratus remained the most abundant in terms of numbers from the pre-impoundment study through out the early years of the reservoir. Currently, however, Barbus macrops has become the most abundant species. In terms of weight, separate post impoundment studies showed Heterotis niloticus and Hydrocynus forskalii as most important in the early years of the reservoir while Chrysichthys nigrodigitatus has become the most important recently.

Changes in trophic status of the fish community: Fig. 2 gives the estimates of relative importance of trophic groups of fish species by different authors since impoundment and gives the basis for changes in the fish community since impoundment. The percentage composition of semi pelagic omnivores in terms of numbers has increased over time from less than $20 \%$ to $51.31 \%$. The percentage composition of benthic omnivores in terms of numbers has been declining from almost $70 \%$ to $20.72 \%$. In terms of weight, however, the percentage composition of benthic omnivores has increased from about $40 \%$ after the first year of impoundment to $52.62 \%$ after 25 years of impoundment. The percentage composition of herbivores by weight after this impoundment period has declined compared with one year after impoundment, whilst the percentage composition of herbivores in terms of numbers has been fluctuating. The current percentage composition of piscivores in terms of numbers $(19.15 \%)$ has declined compared to $70 \%$ in Dankwa (1982). Though semi pelagic omnivores recorded the least values in terms of weight and numbers in two previous post impoundment studies, they have currently increased in value in terms of numbers. In terms of weight, however, semi pelagic omnivores continue to record the least values.

Fishery: The most common species of commercial importance were Chrysichthys spp. and Cichlids which together constituted about $60-70 \%$ of the commercial catches. The clupeid fishery involving mainly Odaxothrissa mento and Sierathrissa spp. was vibrant despite indications of declining catches from fishermen. The fishery is open access and unregulated as in many reservoirs in the tropics. No fishing regulations or management interventions were observed in place or being enforced.

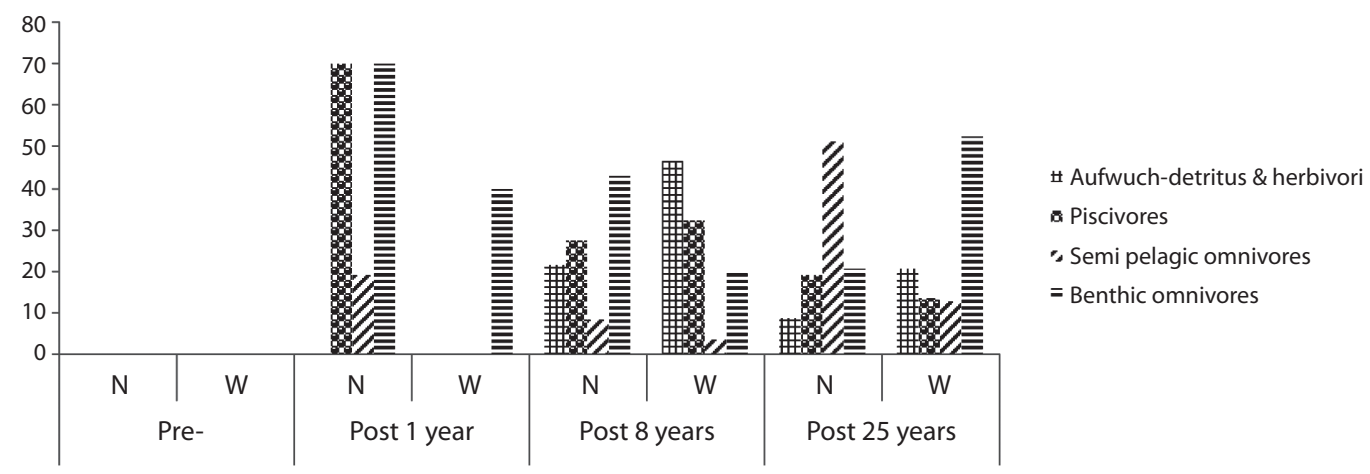

Fig. 2. Estimates of trophic groups of fish in Kpong Headpond during 25 years of impoundment ( $\mathrm{N}$ is percentage number of fish; $\mathrm{W}$ is percentage weight of fish). 
The only exception is the "no fishing day" instituted by the shrines some years earlier. This was being practiced only at Kpong and surrounding villages.

Nine main fishing gears and methods in use include gill nets of different mesh sizes, cast nets, mosquito proof nets, traps of different types, atidja, harpooning as well as hook and line. The most commonly used gear by fishermen over the whole reservoir was gill nets. Traps were fairly common in the rapids and riverine areas of the reservoir, mainly for catching crustaceans and fish species adapted to riverine conditions such as Hydrocynus forskalii and Hepsetus odoe. Destructive fishing practices observed or reported on a regular basis by Quarcoopome \& Amevenku (2010) were the use of mosquito proof nets to catch mainly clupeids as well as the use of explosives (e.g. dynamite) and chemicals (e.g. dichlorodiphenyltrichloethane or DDT) which are known to indiscriminately harvest or kill fingerlings, fry and eggs leading to lower recruitment and loss of fish stocks.

No group or entity was identified as having oversight responsibility for managing and coordinating activities on the reservoir. The Fisheries Directorate of the Ministry of Fisheries is, however, involved in collecting data on fish catches. Consequently, this limited monitoring, control and surveillance of the reservoir, if allowed to continue, will not only serve as a potential catalyst for degradation but also for conflict in view of the multiple uses.

\section{DISCUSSION}

Fish species composition and categorisation: The current fish assemblage of the Kpong Reservoir is the result of restructuring of those fish communities that previously occupied the River Volta, its floodplains and watershed area. The observed disappearance and appearance of fish species indicates that restructuring is still ongoing as expected.

The disappearance of all estuarine species that were trapped after damming has influenced fish species composition. Antwi \&
Ofori-Danson (1993) were of the opinion that the estuarine fishes caught during pre-impoundment and immediately after impoundment were occasional visitors, who were migrating upstream from Ada. They intimate that with the formation of sand bars at Ada estuary after the construction of the dam, such migration of estuarine species has been prevented hence their absence from the area consequently. A study involving the use of several different fishing gear and methods and covering both dry and wet seasons will confirm the disappearance and decline or otherwise of other fish species from the reservoir.

By inference from previous studies, it can be seen that the status of individual fish species has been changing since impoundment, the only exception for now being the permanent category. The sustainability of the reservoir fish and fisheries is given a boost by the fact that $S$. intermedius which appeared recently is included among the important species while six species: B. macrops, H. bimaculatus, $H$. fasciatus, M. deliciosus, S. galileus and S. intermedius which are grouped among the permanent species in the reservoir are also included in the important category.

Changes in relative abundance of the fish community: Fish populations in reservoirs usually increase rapidly in numbers and mass after filling and thereafter fluctuations occur seasonally or from year to year. The latter fluctuations are influenced by the biology of the species and the vagaries of the environment. Knowledge of these changes is, therefore, necessary in order to improve long-term forecasts, plan catches, develop rational ways of fishing and increasing production, conserving stocks and managing the fisheries.

Bhukaswan (1980) noted that many fish species adapt to environmental changes in reservoirs to varying degrees and continue to exist at changed abundance. The alteration of existing ecological and biophysical processes after impoundment such as the slowing of the flow of the river both upstream and downstream and the invasion of aquatic weeds 
have underpinned the changes in the relative abundance of fish species. These factors consequently resulted in the strengthening of the lacustrine species and the suppression or complete disappearance of the riverine species. For instance, the presence of the dam blocks the way downstream for feeding and spawning of fish species such as Brycinus nurse, Brycinus longipinnis, Lates niloticus, Labeo species and Bagrus species. Sedimentation, on the other hand, reduces food supply and spawning grounds for benthophagous species such as Clarias anguillaris, Synodontis ocellifer and Bagrus bajad resulting in their decline over time. The decline or disappearance of riverine species could also be due to the disintegration of the river ecosystem and the elimination of natural flooding cycles resulting in the disruption of life cycles. According to McCully (1996) this phenomenon has led to a reduction in the number of fish species in the world's watersheds.

Conversely, newly created conditions after damming were favourable to limnophilic species and provided good growth rates, successful reproduction and high survival rates. Thus the fish species increased both in numbers of individuals and total biomass (Beckman \& Elrod 1971, Evans \&Vanderpuye 1973, Balon $\&$ Coche 1974, Petr 1975). Some of these fish species include Barbus macrops, Brycinus leuciscus, Chrysichthys nigrodigitatus, Hemichromis bimaculatus, Hemichromis fasciatus and Tilapia guineensis.

Cichlids declined slightly in relative abundance in terms of numbers while in terms of weight they have increased greatly. While characids declined, cyprinids increased in importance in terms of weight. The decline observed in characids could be attributed to their current restricted distribution as indicated by their presence in commercial catches of fishermen fishing in more riverine and fast flowing portions of the reservoir such as the Kpong and Senchi rapids, as well as in waters surrounding and close to the turbines at Natriku in the southern section.
There was a decline in occurrence and relative abundance of Heterotis niloticus (Osteoglossidae), Lates niloticus (Centropomidae), Auchenoglanis occidentalis (Claroteidae), Bagrus spp. (Bagridae), Gymnarchus niloticus (Gymnarchidae), Hepsetus odoe (Hepsetidae) and Hydrocynus forskalii (Characidae) which were predominant one year after impoundment. This decline in occurrence and abundance could be attributed to a combination of factors such as fishermen preference for these species and their vulnerability to selection by specialised fishing gears in addition to unfavourable environmental conditions as well as biological factors. Rounsefell \& Everhart (1953) and Miranda (2001) reported that fishing is an important factor in causing changes in fish species composition (i.e. numbers, size, growth, productivity) as well as the structure and functioning of a fish community.

Chrysichthys nigrodigitatus has experienced extreme proliferation during the period becoming the most important species in terms of weight although it was not observed in the area before impoundment. Though it is not clear what might have caused the proliferation in $C$. nigrodigitatus, it could be enhanced by biological and environmental factors. Similarly Barbus macrops has increased its relative abundance in the Kpong reservoir almost ten times similar to what pertained in the Weija Reservoir after 28 years of impoundment (Quarcoopome \& Amevenku 2006). This was partly attributed to the fishing pressure due to specialization of capture exerted on the larger-sized and more preferred fish species which then encouraged the proliferation of Barbus macrops and Brycinus leuciscus. Singit et. al. (1988) reported similar occurrences in Indian reservoirs.

Changes in trophic status of the fish community: While semi pelagic omnivores have increased in terms of numbers becoming the most important, they continue, however, to be least important in terms of weight. The importance of benthic omnivores in terms of numbers has declined possibly due to sedimentation, which has reduced food resources 
and spawning grounds for benthic fishes. In terms of weight, however, benthic omnivores have increased in their importance and have maintained their dominance in the reservoir. The omnivores together (i.e. both semi pelagic and benthic omnivores) have, however, become most important in terms of both weight and numbers, respectively. Importance of herbivores in terms of weight has declined slightly compared with one year after impoundment whilst in terms of numbers importance of herbivores has been declining possibly due to declining food sources. The general decline in the importance of piscivores in terms of numbers and weight could be attributed partly to the disappearance of some piscivorous fishes as well as their restricted distribution due to their preference for riverine conditions which have reduced over time. Hemichromis fasciatus has maintained its importance as a "fish-eating fish" whereas Epiplatys senegalensis has disappeared and Clarias anguillaris has declined in abundance. Despite changes in trophic status of the fish community, both Antwi \&OforiDanson (1993) and Quarcoopome et al. (2007) recorded forage-carnivore ratios within the recommended range of 1.4 to 10.0 (Blay 1985) indicating suitable ecological balance.

Fishery: The fishes of commercial importance have largely remained Chrysichthys species and cichlids. The dominant Chrysichthys species has, however, shifted from $C$. auratus to $C$. nigrodigitatus while $C$. walkeri and $C$. velifer have declined considerably in importance to the fishery. Biological and environmental factors may account for the shift in important Chrysichthys species. It is a common phenomenon in tropical reservoirs that no one species dominates the fishery for a long time hence it is expected that over time other species apart from Chrysichthys nigrodigitatus would dominate.

The use of mosquito-proof nets in the clupeid fishery is detrimental to the fisheries of the reservoir as eggs, larvae and fry of some fishes are indiscriminately removed resulting in low recruitment and corresponding negative consequences for the species so affected (Quarcoopome \& Amevenku 2010).

To ensure sustainable fisheries, enforcement of fishing regulations and control of access to the fishery by means of monitoring, control and surveillance as well as education of fishermen on the dangers of using destructive fishing gears and methods.

To ensure that conflicting water uses are well managed in order to derive optimum benefit from this multipurpose reservoir, there is a need to constitute a Management Board for the Kpong Headpond. The formation of the Management Board should be done such that the fisheries sector is represented and that fisheries criteria are incorporated into operational guidelines for the dam. In view of the fact that requirements for fish and fisheries of the Kpong Headpond, with regard to management of the water mass and water level may be different from that required for hydroelectric power generation or irrigation, it is necessary that the operations of the reservoir water management be based on an integrated approach taking into account the biological, chemical, physical, socio-economic and other factors.

\section{ACKNOWLEDGMENT}

The authors wish to gratefully acknowledge H.R. Dankwa for his useful suggestions. Yaw Sandoh and the late Nicholas Anawoe who provided field assistance are acknowledged.

\section{RESUMEN}

La laguna Kpong se convirtió en la segunda represa creada en el río Volta, después de Akosombo, principalmente para la generación de energía hidroeléctrica y suministro de agua potable, además, contribuye con la producción pesquera de Ghana desde que se formó la misma. Los cambios en la comunidad de peces de la laguna Kpong fueron estudiados con el fin de proporcionar información de referencia para la formulación de estrategias que contribuyan con el desarrollo socio-económico de la represa. El estudio identificó los cambios en la comunidad de peces de la represa mediante la comparación de la ocurrencia, composición, abundancia relativa y estimaciones de importancia relativa de las especies de peces, familias y grupos tróficos. De manera que con base en 
estudios previos disponibles efectuados en la represa y cotejando tal información con el estado actual de los peces identificados en este sitio, éstos se clasificaron según su presencia e importancia de la siguiente manera: desaparecido, aparecido, permanente, en disminución o importante. Los resultados indicaron que la comunidad de peces ha experimentado un cambio en la composición y abundancia relativa de especies importantes, familias y grupos tróficos en términos de número y peso, aunque continúan permaneciendo ecológicamente balanceados. Representantes de las familias Osteoglossidae, Centropomidae y Characidae han disminuido mientras que los representantes de las familias: Claroteidae, Cyprinidae y Cichlidae han incrementado. Los perifiton-detritívoros y herbívoros disminuyeron, mientras que los omnívoros semipelágicos aumentaron, lo que resulta en un cambio en la dominancia de los bentónicos y los omnívoros semi-pelágicos. La aparición de cinco especies y la desaparición de otras 25 , indica una reestructuración dinámica de la comunidad de peces en la represa, como se esperaba. Para una pesca sostenible en la represa se recomienda la aplicación de reglamentos pesqueros, que incluyan el uso de equipo y métodos de pesca apropiados, control de la pesca, promoción de una cultura basada en la pesca y el mejoramiento de la educación de los pescadores.

Palabras clave: comunidad de peces, Kpong Headpond, embalse, represa.

\section{REFERENCES}

Anon, 1977. Kpong hydroelectric project resettlement programme. Volta River Authority, Akosombo, Ghana.

Antwi, L.A.K. \& P.K. Ofori-Danson. 1993. Limnology of a tropical Reservoir (Kpong Reservoir in Ghana). Trop. Ecol. 34: 75-87.

Balon, E.K. \& A.G. Coche (eds.). 1974. Lake Kariba, a man-made ecosystem in Central Africa. Monogr. Biol. 24: 767.

Beckman, L.G. \& J.H. Elrod. 1971. Apparent abundance and distribution of young-of-year fish in Lake Oahe, 1965-69. Spec. Publ. Am. Fish. Soc. 8: 333-48.

Benneh, G. \& K.B. Dickson. 1980. A new geography of Ghana. Longman, London, England.

Bhukaswan, T. 1980. Management of Asian reservoir fisheries. FAO Fish. Tech. Pap. No 207, Rome.

Blay, J. Jr. 1985. Observations on the balance in fish populations in a small reservoir in Ghana. Fish. Res. 3: 1-11.
Dankwa, H.R. 1982. Changes in the fish fauna of the Kpong Headpond-one year after impoundment. IAB Technical Report, Accra, Ghana.

Evans, W.A. \& J. Vanderpuye. 1973. Early development of the fish populations and fisheries of Volta Lake. Geophys. Monogr. 17: 114-120.

Lévêque, C. \& D. Paugy. 1984. Guide des poissons d'eau douce de la zone du programme de lutte contre l'onchocercose en Afrique de l'Ouest. Convention ORSTOM-OMS, Orstom Paris.

Lévêque, C., D. Paugy \& G.G. Teugels (eds.). 1992. The fresh and brackish water fishes of West Africa, Vol. 2, ORSTOM/MRAC, Paris, France.

Lowe-McConnell, R.H. 1972. Keys for the field identification of freshwater fishes likely to occur in or above the new man-made lakes, Lake Volta in Ghana and the Kainji Lake on the River Niger in Nigeria. Ghana Universities, Accra, Ghana.

McCully, P. 1996. Silenced rivers: the ecology and politics of large dams. Zed Books, London, England.

Miranda, L.E. 1999. A typology of fisheries in large reservoirs of the United States. In N. Am. J. Fish. Manag. 19: 536-550.

Miranda, L.E. 2001. A review of guidance and criteria for managing reservoir and associated riverine environments to benefit fish and fisheries. In G. Marmulla (ed.). 2001. Dams, fish and fisheries: opportunities, challenges and conflict resolution. FAO Fish. Tech. Pap. No 419.

Petr, T. 1975. Hydrobiology and fisheries problems of the Nyumba ya Mungu man-made lake in Tanzania. Afr. J. Trop. Hydrobiol. Fish. 4: 39-50.

Quarcoopome, T. \& F.K.Y. Amevenku. 2006. Fish fauna of the Weija Reservoir-28 years after impoundment. CSIR-WRI Technical Report No 134, Accra, Ghana.

Quarcoopome, T., F.K.Y. Amevenku, K.A. Asante \& F.J. Akpabey. 2007. Ecology and socio-economics of Kpong Headpond-25 Years after impoundment. CSIR-WRI Technical Report No 136, Accra, Ghana.

Quarcoopome, T. \& F.K.Y. Amevenku. 2010. Fish and fisheries of Kpong Headpond-25 years after impoundment. West Africa. J. Appl. Ecol. 16: 51-63. 
Rounsefell, G.A. \& W.H. Everhart. 1953. Fishery science, its methods and applications. John Wiley and Sons Inc., New York, USA.

Singit, G.S., R.P. Reddy \& H.V. Krishnamaraju. 1988. Post impoundment changes and effects of conflicting uses on the fisheries of Tungabhadra Reservoir, India. In S.S. De Silva, (ed.). Reservoir fishery management and development in Asia. Proceedings of a Workshop held in Khatmandu, Nepal, 23-28 Nov. 1987, I.D.R.C., 264, Ottawa, Ontario, Canada.

Vanderpuye, C.J. 1982. Pre-impoundment fish fauna of the Kpong hydroelectric project area, lower Volta, Ghana. Bulletin de 1' LF.A.N.T. 44 ser. A 3-4: 365-383. 